\title{
SOCIOLOGICAL ASPECTS OF MULTICULTURAL ISLAMIC RELIGIOUS EDUCATION
}

\author{
Miftahul Huda \\ Universitas Islam Negeri Syarif Hidayatullah Jakarta \\ e-mail: miftahul1991@gmail.com ${ }^{1)}$
}

\begin{abstract}
This writing aims to analyze the sociological aspects of multicultural Islamic religious education. Multicultural Islamic religious education is a solution to the plurality of Indonesian society in accordance with the democratic principles adopted by the Indonesian nation. Multicultural Islamic religious education is an important aspect in building the nation's next generation. Sociological aspects in multicultural Islamic religious education are fundamentally reflected by the existence of conducive cooperation between Islamic religious education in the family, school and community environment, good educational control will be realized. In a sociological context, the family is the first and foremost institution known to children. In this case, his parents are the first to be known and provide educational values. Then the school environment, the school at this time is a need for everyone to get an education from school. Schools in this case have two important aspects, namely individual aspects and social aspects. On the one hand, schools are tasked with influencing and creating conditions that allow optimal development. Furthermore, the community environment, a diverse society such as in Indonesia often creates the potential for friction or even conflict. Therefore, differences are a necessity in a pluralistic society. Differences must be accepted as a necessity. Such acceptance will lead to people's attitudes that can accept existing differences. This is what will produce students who have good morals, who will not only make their parents and teachers proud, but also the community as users of educational outcomes.
\end{abstract}

Keywords: sociological; Islamic religious education; multicultural. 


\section{A. INTRODUCTION}

The reality that is owned by the Indonesian people is the diversity of religion, ethnicity, culture, language, race, ethnicity and others, so that it becomes a multicultural country. This multicultural reality has the consequence of the importance of wholeness with the motto Bhinneka Tunggal Ika "different but still one" which binds all ethnic and cultural diversity into the nation's superiority.

However, in addition to the advantages possessed by the Indonesian nation as a multicultural country, there are also disadvantages. Weaknesses as a multicultural country, which is prone to conflict. As in East Java in 2012, there was conflict between Sunni and Shia (between religious sects), and there were many other cases such as the burning of places of worship in Ambon, Situbundo, Ahmadiyyah and Gaffatar and the case of Tolikara Papua.

During conflict resolution, the discourse on multicultural education aims to deal with inter-ethnic, socio-cultural conflicts that often occur in multicultural societies. Until now, the multicultural view of this country is like fire. This may be due to political temperatures, religious reasons, so unfortunately the culture is getting hotter, which makes conflicts re-emerge ${ }^{1}$.

Regarding the point of view of identity development related to conflict, there are three types of people who have different points of view $^{2}$, namely, first, the view of primordialism. This view believes that genetic differences of ethnicity, race, and religion are the main source of conflicts of interest between nations and religions. Second, the instrumentalist view. According to them, ethnicity, religion, and other identities are seen as tools used by individuals or groups to achieve greater goals, whether in material or immaterial forms. Politicians and elites use this concept more broadly to gain support than identity pools. For example, by shouting "Islam", all Muslims are expected to unite to

${ }^{1}$ Chairul Mahfud, Pendidikan Multikultural (Yogyakarta: Pustaka Pelajar, 2006).

${ }^{2}$ Mc. Wijaya, Pendidikan Multikultural (Jakarta: Binangkit, 2012). 
support political interests. Therefore, in the instrumentalist view, as long as everyone is willing to submit to the existence expected by the elite, while conflicts between identity sets can be avoided or even occur. Third; Constructivists, who believe that primordial identity is not as rigid as collective identity, and therefore can turn into a powerful social activity in people's lives.

Knowledge of the nature, behavior, and development of society is studied in sociology ${ }^{3}$. So that sociological aspects always take into account the cultural values that live in society. Moreover, if society is associated with Islamic education, these are two interdependent institutions (relational interdependence). The driving force of society depends on the educational process that applies in it, and the driving force of education depends on the response of the community to the strategic position of the world of education ${ }^{4}$. Islamic education that can respond to community problems and is able to provide alternative solutions, will be a meaningful instrument for the dynamics of society. Based on the problems mentioned above, this paper will therefore discuss the sociological aspects of multicultural Islamic religious education.

There are several studies that are relevant to this research. one of them is about how multicultural Islamic religious education in the millennial era like today. Sociologically, multicultural education is an attempt to preserve Islamic values as the vision of Islam rahmatanlil'alamin. Therefore, Islamic education today, faced with various increasingly crucial challenges, this view, cannot be separated from the atmosphere of modernization and globalization. Thus the presence of Islamic education is required to play its role dynamically

${ }^{3}$ Tim Penyusun, Kamus Besar Bahasa Indonesia (KBBI), Kamus Versi Online/ Daring (Dalam Jaringan) (Jakarta: Kemendikbud.go.id, 2016), https://kbbi.web.id/sosiologi.

${ }^{4}$ Muhamad Ansori, "Model Pendidikan Islam Berbasis Multikultural," Jurnal Al$\begin{array}{lllll}\text { Yasini 3, no. } & 2 & \text { (2018): } & 118-32 \text {, }\end{array}$ http://ejournal.kopertais4.or.id/tapalkuda/index.php/alyasini/article/view/3510. 
and is expected to be able to provide change in the midst of a pluralistic society. Thus to build Islamic education in Indonesia which can bring a universal vision, it is necessary to have a paradigm of multicultural Islamic education, by promoting several principles, including; maintaining harmony, peace of mutual respect and liberation, not the other way around as domestication and social taming (social and cultural domestication). In this context, education is referred to as social enlightenment. Therefore, the effort to build the paradigm of Islamic education is a necessity, this can be done by restoring the social values of Islamic education universally besides being dynamic (inclusive), through several stages, namely a) building inclusive awareness by transmitting the entire system socio-religious values such as ketauhidan, tolerance and justice in the curriculum structure (culture domination and control). b) reconstructing the paradigm of Islamic education from the point of view of indoctrination to participatory, c) changing the ideological paradigm into scientific by giving the human mind the freedom to study and develop knowledge through His guidance ${ }^{5}$.

It was further explained that the understanding of pluralism and multiculturalism which has now become a commodity in the political field will continue to roll in the realm of national education, including Islamic religious education which is an integral part of the national education system ${ }^{6}$.

The research was conducted with a qualitative approach. While the analysis with descriptive analysis. Data were collected using literature review/literature studies related to the preservation of

5 Ahmad fauzi, "Paradigma Pendidikan Islam Multikultural Di Era Melenial; Sebuah Kajian Diskurtif," Edurelijia Jurnal Pendidikan Agama Islam 2, no. 1 (2018): 110, https://doi.org/https://doi.org/10.33650/edureligia.v2i1.752.

6 Suyatno, "Multikulturalisme Dalam Sistem Pendidikan Agama Islam: Problematika Pendidikan Agama Islam Di Sekolah," ADDIN; Media Dialektika Ilmu Islam 7, no. 1 (2013): 81-104, https://journal.iainkudus.ac.id/index.php/Addin/article/view/571. 
physical and digital content in university libraries ${ }^{7}$. Another term for Literature Study is literature study. In this literature study, there are several work procedures or processes to be carried out, namely criticizing, comparing, summarizing, and synthesizing literature. Thus, it can be understood that this research was conducted by means of a literature study, where the emphasis is more on peeling, ranking and collecting existing literature, for further analysis of the existing data.

The formulation of the problem in this paper are 1) How is multiculturalism in Islamic religious education?; 2) What are the sociological aspects of multicultural Islamic religious education? The purposes of this paper are 1) To find out multiculturalism in Islamic religious education; 2) To identify the sociological aspects of multicultural Islamic religious education.

\section{B. MULTICULTURALISM IN ISLAMIC RELIGIOUS EDUCATION}

The term "Multiculturalism" is inadequate to be understood literally as "understanding of many cultures" ${ }^{8}$. Multiculturalism includes ideas, perspectives, policies, attitudes and actions, by the people of a country that is diverse in terms of race, ethnicity, culture, religion, and so on, but has aspirations to develop the same national spirit and have pride. to maintain this diversity.

The traditional understanding of multiculturalism has two main characteristics; first, the need for recognition. Second, the legitimacy of cultural diversity or cultural pluralism ${ }^{9}$. On the other hand, there are also figures who state that multiculturalism is basically a world view which can then be translated into various cultural policies that

7 Lexy J. Moleong, Metodologi Penelitian Kualitatif (Bandung: Remaja Rosdakarya, 2018).

${ }^{8}$ Ahmad Rifai Harahap, "Multikulturalisme Dalam Bidang Sosial,” Etnovisi: Jurnal Antropologi Sosial Budaya II, no. 1 (2006): 32-35.

${ }^{9}$ H. A. R Tilaar, Multikulturalisme; Tantangan-Tantangan Global Masa Depan Dalam Pendidikan Nasional (Jakarta: Grasindo, 2002).

Miftahul Huda 
emphasize acceptance of pluralist and multicultural religious realities that exist in people's lives ${ }^{10}$. So it can be concluded that multiculturalism is an understanding of the acceptance of pluralism in society in order to avoid horizontal conflicts in society.

Referring to Bikhu Parekh the term multiculturalism contains three components, namely, first, culture; second, referring to cultural plurality; and third, it contains a certain way of responding to plurality 11. The suffix "ism" denotes a normative doctrine that is expected to work for everyone in the context of a multicultural society. In this case, the starting point is how multiculturalism as a normative doctrine can pose to exist. Henceforth, these multicultural ideas are implemented through political policies, especially education policies.

Multicultural education is usually defined as education for the cultural diversity of the community. There are also those who interpret it as education that provides various models for various cultures in society. Then there are also those who interpret it as education to build a spirit of mutual respect for the cultural diversity of the community ${ }^{12}$.

Sleeter and Grant in Calarry Sada suggest that multicultural education has four meanings (models), namely, (1) teaching that uses a cultural assimilation approach, (2) teaching with an approach in social relations, (3) teaching that aims at to promote pluralism without differentiating social strata in society, and (4) teaching about reflection on diversity to promote pluralism and equality ${ }^{13}$. Basically, multicultural education is a renewal movement that proceeds to provide an equal educational environment for all students.

${ }^{10}$ Azyumardi Azra, Identitas Dan Krisis Budaya, Membangun Multikulturalisme Indonesia (Jakarta: FE UI, 2007).

${ }^{11}$ Bikhu Parekh, Rethinking Multiculturalism: Cultural Diversity and Political Theory (Cambridge, Mass: Harvard University Press, 2000).

12 Kamanto Sunarto, "Multicultural Education in Schools, Challenges in Its Implementation," Jurnal Multicultural Education in Indonesia and South East Asia I (2004): 47.

${ }^{13}$ Clarry Sada, "Multicultural Education in Kalimantan Barat; an Overview," Jurnal Multicultural Education in Indonesia and South East Asia I (2004): 85. 
The ultimate goal of multicultural education is to form the younger generation in addition to being knowledgeable and skilled and able to live together in society ${ }^{14}$. James A. Bank provides an understanding that multicultural education aims to explore existing differences and diversity so that it can be internalized in all types of subjects by gradually changing behavior through the application of learning materials such as aspects of morality, discipline, humanistic care, ethical honesty, and empathic life ${ }^{15}$. In this case, it is also in the context of training and building the character of students so that they can be democratic, humanist and pluralist by creating a more pluralist and inclusive religious understanding in the environment where they are located.

Multicultural-based Islamic education emphasizes the continuity of the effective learning process (effective teaching), and active learning (active learning), in this case how teaching about religion is a priority (teaching about religion), not teaching religion (teaching about religion). of religion) ${ }^{16}$.

Islamic education must have a frame of mind that the faith of religious adherents is dialogical, meaning that faith can be communicated dialogically between God and humans as well as between human beings. An educational atmosphere like this will create a sense of togetherness and comfort in religious life, differences that do not cause conflict, there is no such thing as superior or inferior, and a dialogical atmosphere that will open up new spiritual insights related to each other's sense of religiosity and faith. Such conditions can be created through inclusive faith education. The objectivity and subjectivity of religious teaching like this are highly demanded in this

\footnotetext{
${ }^{14}$ Amir Rusdi, "Perspektif Islam Tentang Keberagaman Dan Penyikapannya Dalam Konteks Pengembangan Kurikulum PAI," Conciencia 1, no. 2 (2007): 50.

15 James A. Banks, Multicultural Education: Issues and Perspectives (BostonLondon: Allyn and Bacon Press, 2010).

16 Kasinyo Harto, Model Pengembangan Pendidikan Agama Islam Berbasis Multikultural (Jakarta: RajaGrafindo Persada, 2012).
} 
regard. Objective means being aware that talking about many faiths is fair without having to ask questions about the truth or validity of a religion. Subjective means that there is a moral awareness that such teaching is only to lead each student to understand and feel the extent to which faith in a religion can be felt by those who believe in it. So in this case, multiculturalism in Islamic religious education actually provides students with an understanding that Islam is very open and dialogical so that all students feel a sense of togetherness and have equal opportunities in the learning process.

\section{SOCIOLOGICAL ASPECTS OF MULTICULTURAL ISLAMIC RELIGIOUS EDUCATION}

The word sociology was first used by the father of sociology named Auguste Comte, where the title of his writing was Cours de Philosopie Positive (Positive Philosophy) which was written in 1842. Sociology comes from Latin which is from two words; Socius and Logos. Etymologically or literally the word socius means; friend, comrade, friend, while logos means knowledge ${ }^{17}$. Thus it can be understood that sociology means the science of how to make friends, be friends. Or with another understanding that sociology is a science that talks about how to get along with the community, in other words sociology studies society/science about people's lives.

Broadly speaking, there are three opinions about the object of sociology ${ }^{18}$, namely:

1. The object of sociology is the individual (individualism). George Simmel is the character. This object views society from the point of view of the individual; The unity of the group originates solely from a tangible unit consisting of individual humans. George Simmel focuses on the power of influence between individuals which is the source of all group formation.

17 Tjipto Subadi, Sosiologi Dan Sosiologi Pendidikan Suatu Kajian Boro Dari Perspektif Sosiologis Fenomenologis (Kartasura, 2009).

18 Tjipto Subadi. 
2. The object of sociology is a group of people/society (collectivism). The character is Ludwik Gumplowicz. According to him the only object of sociology is society or human groups. In historical events, the individual is passive where his spiritual life is determined by the will of society. Ludwik's attention was mainly devoted to the struggle between the groups.

3. The object of sociology is social reality. The individualistic and collectivistic views mentioned above are usually seen as one-sided, therefore this third view wants to avoid this weakness. This view views social life from the point of view of mutual influence and impartiality towards the contradictions between the two ideologies. There are even those who do not acknowledge the contradiction that exists between the two ideologies.

For this view, there are two figures who adhere to this understanding. first, Ch. H. Cooley, who holds that sociology is aimed at social reality. These concepts are also developed from the interdependence and inseparability of the individual and society. "Society and the individual self are twins." Likewise, individual consciousness cannot be separated from social consciousness. Cooley put forward the theory that the social life of society is a whole. Individuals and society cannot stand alone, but both are facets of a reality. "primary groups" such as family, neighborhood, friend environment and so on is an important thing from this theory. Primary group with close face to face relationship, is a place to print all one's personal attitudes and social attitudes.

In this case L. Von Wiese. Mention that Beziehunglehre sociology, is the science of human relations, or social relations. Sociology is seen as an empirical science and its object is the relationship between humans in social formation. The basis of sociological investigation is social relations / social processes, namely changes in social distance (changes in the distance of social relations), especially in terms of paying attention to social processes of "association" (connection) and "disassociation" (split). . In a social 
setting, he only sees processes and a series of events which of course also involve individuals.

Basically the object of sociology is society. Society in this case is a society that has relationships between humans and processes that arise from relationships between humans in society itself ${ }^{19}$. Society is a group of people who live together occupy a place of residence into a single unit and have a common life system. This system of living together then gives rise to culture, including the living system itself.

Some aspects studied in sociology include ${ }^{20}$ :

1. Reciprocal relationships between individuals with other individuals. An example of this is when we look at a leader and a follower who have a typical interaction. A follower always lowers his gaze when meeting or passing his leader and carrying out his leader's orders. The phenomenon of the interaction of these two people has become the object of sociological study.

2. The relationship between individuals and groups. An example is the social role between father and mother. A father works in the office or a mother works at home. The choice to play a social role is influenced by their views on how to build a family. Father or mother are individuals. Meanwhile, the family is a group.

3. The relationship between one group and another. An example is the inter-ethnic conflict that occurred in Kalimantan several years ago. This inter-ethnic or tribal dispute is a conflictual relationship. This relationship is a form of relationship between community groups. Sociology can study it from several dimensions. For example, from the identity dimension, where the two groups use ethnic identity to be hostile to each other.

4. Characteristics or characteristics of diverse social groups. Social differentiation and social stratification are two of the most studied

${ }^{19}$ Jabal Tarik Ibrahim, Sosiologi Pedesaan (Malang: Universitas Muhammadiyah, 2003).

${ }^{20}$ Sidiqharim, "Ruang Lingkup Sosiologi: Beberapa Contoh Referensi Ilmu Sosial Di Era Digital,” Sosiologi.com, n.d., http://sosiologis.com/ruang-lingkup-sosiologi. 
basic concepts of sociology. Differences in social groups both vertically and horizontally can be the object of sociological study. For example, why do some people occupy the upper social class and some find it difficult to move up to the lower class, or even get stuck in the middle class.

The socio-cultural aspect is a fundamental aspect that provides a socio-cultural framework, in which socio-cultural education is carried out. This aspect also acts as a benchmark in learning achievement. That is, the high and low of an education can be measured from the level of relevance of education output to the needs and desires of the community. Good education is education that does not lose its context or is uprooted from its community roots. Educational achievements are almost useless if they damage the fabric of society. Likewise, a good society will organize a good education format as well.

Islamic religious education and society are like two sides of a coin that cannot be separated. Because Islamic religious education has the responsibility to answer all the problems that exist in social reality by trying to contextualize the source texts of Islamic teachings with the social (reality) context that surrounds them, so that the text cannot be separated from its context, namely the present. (nowness) and here (hereness).

Moreover, the Indonesian nation as a pluralistic nation, on the one hand is a wealth to be grateful for, on the other hand this pluralistic Indonesian nation is precisely the threat of social disintegration ${ }^{21}$. Multicultural Islamic education, has an important place to direct the individual development of students in viewing plurality in their lives, mentally preparing students to be willing to accept existing and growing outside themselves ${ }^{22}$.

${ }^{21}$ Abdullah Idi, Dinamika Sosiologis Indonesia: Agama Dan Pendidikan Dalam Perubahan Sosial (Yogyakarta: LKiS Pelangi Aksara, 2015).

${ }^{22}$ Abdullah Ali, Pendidikan Islam Multikultural Di Pesantren, Telaah Terhadap Kurikulum Pondok Pesantren Modern Islam as -Salam Surakarta (Yogyakarta: Pustaka Pelajar, 2011).

Miftahul Huda 
Thus, the sociological aspects of multicultural Islamic religious education are conducive to cooperation between the family, school and community environment. All three are a unified whole and complement each other. All three must be able to carry out their functions as a means of providing motivation, educative facilities, a vehicle for developing the potential that exists in students and directing them to be able to be of effective-efficient value in accordance with the development and needs of their time and provide guidance and serious attention to the moral-spiritual needs of participants. students so that students accept differences and diversity to be able to be democratic, humanist and pluralist by building a more pluralist and inclusive religious understanding in their environment.

The following is a description of the sociological aspects of multicultural Islamic religious education, as follows:

\section{Family Environment}

In a sociological context, the family is the first and foremost institution known to children. In this case, his parents are the first to be known and provide educational values. The guidance, attention, and affection of both parents are a powerful foundation or foundation for the growth and development of psychic and social and religious values in a child.

The family is a group united by marriage, blood or adoption. On the other hand, families are also people who live together in one house and form a household that is a unit and interact with each other, communicate, maintain a common culture that comes from the surrounding environment or create their own culture. The family is also the first and foremost educational environment, not solely for chronological reasons, but from the point of view of the intensity and quality of influence received by the child as well as 
in terms of the responsibilities that parents carry with regard to their child's education ${ }^{23}$.

Based on the description above, in this case the family has several important functions, namely: basic moral and spiritual development functions, educational functions, reproductive functions, economic functions, protective/protective functions, recreational functions, social functions, and affective functions.

Abdullah Ali explained that there are three characteristics of multicultural education, namely:

a. Have the principles of democracy, equality and justice.

b. Have an orientation to humanity, togetherness, and peace.

c. Developing an attitude of acknowledging, accepting and appreciating cultural diversity ${ }^{24}$.

Allah SWT has prescribed in the Qur'an about Islamic religious education in the family. Then the hadith of the Prophet Muhammad SAW has given its interpretation, including; QS. AtTahrim: 6, the translation: "O you who believe, protect yourselves and your families from the fire of hell whose fuel is people and stones; guardians of the angels who are harsh, harsh, and do not disobey Allah in what He commands them and always do what is commanded."

Rasulullah SAW said: "All children are born with a fitrah (religious talent), so it is up to their parents to make them a Judaism, Christian or Magian religion" (HR.Muslim).

Based on the description above, both the Qur'an and Hadith indicate that Islamic religious education is a very important education in the family. Education in the family given by parents

23 Rhoni Rodin; Miftahul Huda, Ilmu Pendidikan Islam Membangun Profesionalisme Pendidik Dan Kependidikan Islam Berbasis Karakter Keteladanan (Yogyakarta: Azyan Mitra Media, 2020).

${ }^{24}$ Abdullah Ali, Pendidikan Islam Multikultural Di Pesantren, Telaah Terhadap Kurikulum Pondok Pesantren Modern Islam as -Salam Surakarta.

Miftahul Huda 
to children is the basic foundation on which children think and develop physically, spiritually and mentally.

Thus, the application of multicultural Islamic religious education can be carried out in Islamic households that accept religious differences and diversity, equality, justice, togetherness, peace, respect for cultural diversity both within the family and with outsiders.

The characteristics of an Islamic household are as follows ${ }^{25}$ : (1) the enforcement of Islamic etiquette in the household, both individually and for all family members; (2) the foundation of worship is the foundation of its establishment, every activity is always directed or based on God, advising each other in truth and patience, instructing each other to do good and forbid what is evil because of their love for Allah; (3) Be a role model for society and the ummah, living in the coolness of faith and spiritual wealth; (4) create an atmosphere of baiti jannati (my household is heaven for me).

Islam views that the process of socializing and inculcating values in children practically starts from the moment the child is born. However, in Islam it turns out that children's education must begin long before their birth. Theoretically, efforts to inculcate the values of multicultural Islamic education have started since the beginning of the selection of a mate ${ }^{26}$. This is reinforced by the Hadith of the Prophet Muhammad which hints that there are four criteria for choosing a mate, namely because of his beauty, wealth, descent, and religion. In this case, the Prophet emphasized that religious criteria are the main criteria in order to foster a sakinah family situation with an Islamic nuance. Furthermore, during

${ }^{25}$ Siti Maryam, Pendidikan Agama Dalam Keluarga Dan Masyarakat (Materi Orientasi Keluarga Sakinah Balai Diklat Keagamaan Jakarta, n.d.).

${ }^{26}$ Murdianto, "Mengurai Eksistensi Lingkungan Pendidikan Islam Perspektif Sosiologis," Sangkep: Jurnal Kajian Sosial Keagamaan 1, no. 1 (2018): 85-107, https://doi.org/10.20414/sangkep.v1i1.607. 
pregnancy, give the child a good name, and choose a good child's playmate $^{27}$.

So it can be concluded that the family environment is one of the sociological aspects in multicultural Islamic religious education if parents in educating children by instilling multicultural values such as accepting religious differences and diversity, equality, justice, togetherness, peace, respecting cultural diversity. Until the creation of baiti jannati (my house is my heaven). Thus, children will not be group fanatics, exclusive in religion, and indifferent to not caring about the environment.

\section{School Environment}

School is the second environment after family. School is a formal educational institution as a place for students to study or is called a learning building ${ }^{28}$. Schools are important educational institutions both in the past and in the present. Schools today are a necessity for everyone to get an education from school. Schools in this case have two important aspects, namely individual aspects and social aspects. On the one hand, schools are tasked with influencing and creating conditions that allow optimal development. In this case, schools are required to be able to record all phenomena that occur in society. On the other hand, schools also provide information and explanations to students regarding ontological events ${ }^{29}$.

Although schools are a means of transforming the culture of a society, their existence is not as broad as culture in general. Its existence is only a subculture of the totality of human culture. This makes the school as the institution that has the greatest role in the dynamics of human culture. In this case, there are three factors behind it, namely: First, the school is a gathering place for students,

27 Rhoni Rodin; Miftahul Huda, Ilmu Pendidikan Islam Membangun Profesionalisme Pendidik Dan Kependidikan Islam Berbasis Karakter Keteladanan.

${ }^{28}$ Moh Fadil, Sosiologi Pendidikan (Malang: UIN Maliki Press, 2007).

${ }^{29}$ Damser, Pengantar Sosiologi Pendidikan (Jakarta: Kencana, 2008). 
who come from various different cultural backgrounds. Schools in this case have a function to accumulate various forms of the cultural background of students, in a form of a cultural system. Second, the existence of the school as a miniature to see how far the progress of a country's civilization. Third, school as a place to forge students to have skills that can be pragmatically predicted in their lives. On the other hand, schools are also places for the growth of religious morality values. With this value, it is hoped that it will be able to become a control tool in every activity it does.

Based on the description above, basically there are eight functions of schools, namely: firstly preparing students to get decent jobs, secondly equipping them with basic skills, thirdly providing opportunities to improve fate, fourthly preparing development workers, fifthly participating in providing solutions to social problems, sixthly transmitting culture, the seventh forms social human beings, and the eighth transforms culture ${ }^{30}$.

The description above provides an understanding that the existence of schools is placed as the most vital means in the process of the emergence of the whole human personality, especially in the context of instilling multicultural Islamic religious education. Therefore, the most fundamental thing about this school environment in the view of Islam is that there are educators who can be nurtured and imitated, namely the only words with actions that can provide examples in life. Words should be directly proportional to actions. Teachers have an important role to instill and teach multicultural Islamic religious education in the school environment. In a practical level a teacher does not distinguish gender, race, ethnicity, ethnicity, and culture in the division of tasks. Instilling the values of peace and democracy, so that students can accept differences and not be fanatical about groups. The formation of students' perspectives in learning Islamic religious

${ }^{30}$ S Nasution, Sosiologi Pendidikan (Jakarta: Bumi Aksara, 1995). 
education with a multicultural perspective can also be achieved through the enrichment of Islamic literature containing plural or multicultural Islamic knowledge. So that students can find that all cultural or religious groups, no matter how small, have a significant contribution to the civilization of a people or nation. A balanced program of providing multicultural literature is expected to accommodate sources that open opportunities for all kinds of aspirations from various sociometric levels, with different positions and with different human characteristics.

\section{Community Environment}

A diverse society such as in Indonesia often creates the potential for friction or even conflict. Therefore, differences are a necessity in a pluralistic society. Differences must be accepted as a necessity. Such acceptance will lead to an attitude of society that can accept existing differences. When what is expected is harmony and an end to existing social conflicts, it is the same as living in an imagination that is too ideal to be real ${ }^{31}$.

Departing from the description above, multicultural Islamic religious education is a solution for the plurality of Indonesian society in accordance with the democratic principles adopted by the Indonesian people. On the other hand, the community should participate in improving the democratic climate of education, for example in the form of community-based education in which the pluralistic values of the Indonesian nation are applied.

Furthermore, the community environment can also play a role in shaping the character of children. For example, the neighborhood where you live is close to the mosque. Children around the mosque will tend to be more diligent in worshiping and participating in activities carried out at the mosque, such as praying, or learning to read the Koran. This kind of environment

31 Manneke Budiman, Multikulturalisme: Antara Kekhawatiran Dan Harapan (Jakarta: FIB UI, 2003).

Miftahul Huda 
will certainly affect the character of the child to be pious, and accustomed to carrying out obligations as Muslims. On the other hand, children will learn to understand the ukhuwah Islamiyah that is formed from every meeting in the mosque for congregational prayers. Therefore, an environment like this can create a dynamic, religious, harmonious life atmosphere and please the people who live in the environment. Then, with environmental conditions like this, it will shape the character of children who are polite, adaptable, empathetic, and can become human beings with a social spirit.

So it can be concluded that the sociological aspects of multicultural Islamic religious education are fundamentally reflected in the conducive cooperation between Islamic religious education in the family, school and community environment. This condition will realize good education control. This is what will produce students who have good morals, who will not only make parents and teachers proud, but also the community as users of educational outcomes. Thus it is clear that responsibility in Islam is individual and social. Thus, it can be understood that the sociological aspect of multicultural-based Islamic religious education occupies a strategic position in creating a peaceful society and can accept the differences that exist in society.

\section{CONCLUSION}

Multiculturalism in Islamic religious education ideally teaches Islam openly and dialogically to students so that all students have equal opportunities and do not discredit other religions that are not the same as the religion of the religious teacher.

The sociological aspects of multicultural Islamic religious education are reflected fundamentally by the existence of conducive cooperation between Islamic religious education in the family, school and community environment. This conducive environment will realize good education control. Such conditions will produce students who have good morals, make parents and teachers proud, as well as the 
community as users of educational outcomes. Thus it is clear that responsibility in Islam is individual and social. So that it can be understood that the sociological aspect of multicultural-based Islamic religious education occupies a strategic position in creating a peaceful society and can accept the differences that exist in society. 


\section{REFERENCES}

Abdullah Ali. Pendidikan Islam Multikultural Di Pesantren, Telaah Terhadap Kurikulum Pondok Pesantren Modern Islam as -Salam Surakarta. Yogyakarta: Pustaka Pelajar, 2011.

Abdullah Idi. Dinamika Sosiologis Indonesia: Agama Dan Pendidikan Dalam Perubahan Sosial. Yogyakarta: LKiS Pelangi Aksara, 2015. Ahmad fauzi. "Paradigma Pendidikan Islam Multikultural Di Era Melenial; Sebuah Kajian Diskurtif.” Edurelijia Jurnal Pendidikan Agama Islam 2 , no. 1 (2018): $1-10$.

https://doi.org/https://doi.org/10.33650/edureligia.v2i1.752.

Ahmad Rifai Harahap. "Multikulturalisme Dalam Bidang Sosial." Etnovisi: Jurnal Antropologi Sosial Budaya II, no. 1 (2006): 32-35.

Amir Rusdi. "Perspektif Islam Tentang Keberagaman Dan Penyikapannya

Dalam Konteks Pengembangan Kurikulum PAI." Conciencia 1, no. 2 (2007): 50.

Azyumardi Azra. Identitas Dan Krisis Budaya, Membangun Multikulturalisme Indonesia. Jakarta: FE UI, 2007.

Bikhu Parekh. Rethinking Multiculturalism: Cultural Diversity and Political Theory. Cambridge, Mass: Harvard University Press, 2000.

Chairul Mahfud. Pendidikan Multikultural. Yogyakarta: Pustaka Pelajar, 2006.

Clarry Sada. "Multicultural Education in Kalimantan Barat; an Overview." Jurnal Multicultural Education in Indonesia and South East Asia I (2004): 85

Damser. Pengantar Sosiologi Pendidikan. Jakarta: Kencana, 2008.

H. A. R Tilaar. Multikulturalisme; Tantangan-Tantangan Global Masa Depan Dalam Pendidikan Nasional. Jakarta: Grasindo, 2002.

Jabal Tarik Ibrahim. Sosiologi Pedesaan. Malang: Universitas Muhammadiyah, 2003.

James A. Banks. Multicultural Education: Issues and Perspectives. BostonLondon: Allyn and Bacon Press, 2010.

Junaidi, Junaidi. "Model Pendidikan Multikultural." Al-Insyiroh: Jurnal 
Studi Keislaman 2.1 (2018): 57-72.

Kamanto Sunarto. "Multicultural Education in Schools, Challenges in Its Implementation." Jurnal Multicultural Education in Indonesia and South East Asia I (2004): 47.

Kasinyo Harto. Model Pengembangan Pendidikan Agama Islam Berbasis Multikultural. Jakarta: RajaGrafindo Persada, 2012.

Putra, M. Kholil Baita. "Eksistensi Sistem Pesantren Salafiyah dalam Menghadapi Era Modern." Al-Insyiroh: Jurnal Studi Keislaman 1.1 (2015): 87-104.

Lexy J. Moleong. Metodologi Penelitian Kualitatif. Bandung: Remaja Rosdakarya, 2018.

Manneke Budiman. Multikulturalisme: Antara Kekhawatiran Dan Harapan. Jakarta: FIB UI, 2003.

Mc. Wijaya. Pendidikan Multikultural. Jakarta: Binangkit, 2012.

Moh Fadil. Sosiologi Pendidikan. Malang: UIN Maliki Press, 2007.

Muhamad Ansori. "Model Pendidikan Islam Berbasis Multikultural."

Jurnal Al-Yasini 3, no. 2 (2018): 118-32. http://ejournal.kopertais4.or.id/tapalkuda/index.php/alyasini/article/vi ew/3510.

Murdianto. "Mengurai Eksistensi Lingkungan Pendidikan Islam Perspektif Sosiologis." Sangkep: Jurnal Kajian Sosial Keagamaan 1, no. 1 (2018): 85-107. https://doi.org/10.20414/sangkep.v1i1.607.

Ramdhan, Tri Wahyudi. "Dimensi Moderasi Islam." Al-Insyiroh: Jurnal Studi Keislaman 2.2 (2018): 29-48.

Ramdhan, Tri Wahyudin. "Model Pengembangan Kurikulum Multikultural." Al-Insyiroh: Jurnal Studi Keislaman 5.2 (2019): 3953.

Rhoni Rodin; Miftahul Huda. Ilmu Pendidikan Islam Membangun Profesionalisme Pendidik Dan Kependidikan Islam Berbasis Karakter Keteladanan. Yogyakarta: Azyan Mitra Media, 2020.

S Nasution. Sosiologi Pendidikan. Jakarta: Bumi Aksara, 1995.

Sidiqharim. "Ruang Lingkup Sosiologi: Beberapa Contoh Referensi Ilmu Sosial Di Era Digital.” Sosiologi.com, n.d. 
http://sosiologis.com/ruang-lingkup-sosiologi.

Siti Maryam. Pendidikan Agama Dalam Keluarga Dan Masyarakat. Materi Orientasi Keluarga Sakinah Balai Diklat Keagamaan Jakarta, n.d.

Suyatno. "Multikulturalisme Dalam Sistem Pendidikan Agama Islam: Problematika Pendidikan Agama Islam Di Sekolah." ADDIN; Media Dialektika Ilmu Islam 7, no. 1 (2013): 81-104. https://journal.iainkudus.ac.id/index.php/Addin/article/view/571.

Tim Penyusun. Kamus Besar Bahasa Indonesia (KBBI), Kamus Versi Online/ Daring (Dalam Jaringan). Jakarta: Kemendikbud.go.id, 2016. https://kbbi.web.id/sosiologi.

Tjipto Subadi. Sosiologi Dan Sosiologi Pendidikan Suatu Kajian Boro Dari Perspektif Sosiologis Fenomenologis. Kartasura, 2009. 